\title{
Demir Eksikliği Anemisi Olan Premenapozal Kadınlarda Serum HbA1c Düzeylerinin Değerlendirilmesi
}

\author{
Eray ATALAY ${ }^{1}$, Ömer KARAAĞAÇ ${ }^{2}$, Kaan TUR $^{1}$, Pınar ŞISSMAN $^{3}$ \\ 1 Kafkas Üniversitesi Tıp Fakültesi, İç Hastalıkları Anabilim Dalı, Kars. \\ 2 Çumra Devlet Hastanesi, İç Hastalıkları Kliniği, Çumra. \\ 3 Medicana Hastanesi, Endokrinoloji ve Metabolizma Hastalıkları Kliniği, Bursa.
}

\begin{abstract}
ÖZET
Yapılan araştırmalarda demir eksikliği anemisi (DEA)'nin HbA1c düzeylerine etkisi tam olarak aydınlatılamamıştır. Muhtemel nedenler arasında hemoglobinin kuarterner yapısındaki değişimler ve $\beta$ globin zincirindeki glukasyonun DEA hastalarında kolaylaşmış olması ihtimali üzerinde durulmaktadır. Çalışmamızda diyabetik olmayan premenopozal kadınlarda DEA'nin HbA1c düzeyine olan etkisinin araştırılması planlanmıştır. Çalışmamıza merkezimiz iç hastalıkları polikliniğine başvuran 18-46 yaş arası premenopozal 91 hasta dahil edildi. Bu bireylerden hemoglobin değeri $12 \mathrm{mg} / \mathrm{dl}$ altında olan 45 birey hasta grup, hemoglobin değeri $12 \mathrm{mg} / \mathrm{dl}$ ve üzerinde olan sağlıklı 46 birey ise kontrol grubu olarak sınıflandırıldı. Çalışmaya alınan grupların hemogram ve diğer demir parametrelerinin (demir, demir bağlama kapasitesi, total demir bağlama kapasitesi, ferritin, transferrin satürasyonu) HbA1c ile arasındaki ilișki araştırıldı. Çalıșmamıza dahil edilen hastaların yaş ortalaması DEA'si olan grupta $32 \pm 10$ yıl, kontrol grubunda ise $30 \pm 8$ yıl idi. Demir eksikliği anemisi olan grubun serum HbA1c düzeyi,

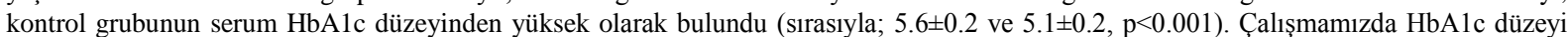
DEA olan grupta istatiksel olarak anlamlı yüksek saptanmıştır. Çalışmamız sonucunda HbA1c düzeyleri yorumlanırken DEA ve diğer olası hata kaynakları konusuna dikkat edilmesi gerektiği kanaatine varılmıştır. DEA'nin etkin tedavisinin aneminin olumsuz etkilerini ve HbA1c yorumlanmasında oluşacak hataları ortadan kaldıracağı düşünülmektedir.
\end{abstract}

Anahtar Kelimeler: Demir Eksikliği Anemisi. HbA1c. Ferritin. Anemi.

Evaluation of Serum HbA1c Levels in Premenopausal Women With Iron Deficiency Anemia

\section{ABSTRACT}

The effects of iron deficiency anemia (IDA) on HbA1c levels have not been elucidated. Possible causes include changes in the quaternary structure of hemoglobin and the possibility of facilitating glucose in the $\beta$ globin chain in the patients with IDA. In our study, it was planned to investigate the effect of IDA on HbA1c in non-diabetic individuals. Ninety-five premenopausal patients aged between 18-46 years who were admitted to our outpatient clinic were included in our study. Forty-five patients with hemoglobin value below $12 \mathrm{mg} / \mathrm{dl}$ were classified as patient group and forty-six healthy subjects with hemoglobin value upper $12 \mathrm{mg} / \mathrm{dl}$ were classified as control group. The relationship between the hemogram and other iron parameters (iron, total iron binding capacity, ferritin, transferrin saturation) of the study groups were investigated. The mean age of the patients included in our study was $32 \pm 10$ years in the patient group and $30 \pm 8$ years in the control group. The HbA1c level was \%5.6 \pm 0.2 in the IDA group and \%5.1 \pm 0.2 in the control group.HbA1c level of the control group was The difference between the groups was statistically significant ( $\mathrm{p}<0.001$ ). In our study, HbA1c level was significantly higher in the group with IDA. As a result of our study, it was concluded that IDA and other possible sources of error should be considered when interpreting HbA1c levels. It is thought that effective treatment of RIA will eliminate the negative effects of anemia and the errors that will occur in the interpretation of HbA1c.

Key Words: Iron deficiency anemia. HbA1c. Ferritin. Anemia.

Geliş Tarihi: 25 Ekim 2018

Kabul Tarihi: 03 Temmuz 2019

Dr. Pınar ŞişMAN

Medicana Hastanesi Endokrinoloji ve Metabolizma

Hastalıkları Kliniği, Bursa

Tel.: 05321550811

E-posta: drpinarsisman@gmail.com
Demir dünyada bol bulunan bir element olmasina rağmen demir eksikliği anemisi (DEA) sıkça gözlenmektedir. Demir, tüm canlılar için biyolojik öneme sahip vazgeçilmez bir element olmakla beraber canlı organizmasında ancak eser miktarda bulunmaktadır ${ }^{1}$. Demirin vücuttaki en önemli görevi hemoglobin arac1lığ1 ile oksijen taşımaktır. Demirin kullanımında, taşınmasında ve depolanması sirasında hücrelerde ve vücut sıvılarında daima ferröz $(\mathrm{Fe}+2)$ veya ferrik $(\mathrm{Fe}+3)$ şekilde bulunur. Pek çok enzimin yapı ve fonksiyonu için gereklidir. Elektron alıp verme özelli- 
ği ile oksijen taşınması, enerji yapımı, DNA, RNA ve protein sentezinde yer alır ${ }^{2,3}$. Demir Eksikliği Anemisi eritrositlerde hipokromi ve mikrositoz, serum demir ve serum ferritin düzeyinin azalması, transferrin satürasyonunun \%15'in altına düşmesi ve total demir bağlama kapasitesinin artması ile karakterizedir ${ }^{4}$.

Diabetes Mellitus (DM) tanısında Dünya Sağlık Örgütünün, 2010 yılında yayımladığı Konsültasyon Raporu'nda, güvenilir bir yöntemin kullanılması ve uluslararası referans değerlerine göre standardize edilmesi koşulu ile HbA1c değerinin \%6.5 ve üzeri olmasının tanı testi parametrelerinden biri olarak kullanılabileceğini önermiştir ${ }^{5}$. Yetişkinlerde total hemoglobinin \%97 sini oluşturan $\mathrm{HbA}\left(\mathrm{HbA}_{1}\right) 2$ alfa ve 2 beta olmak üzere 4 polipeptit zincirinden oluşur. 1966 yılında HbA1c nin yapı olarak HbA ile aynı olduğu ve tek farkının HbA1c beta zincirinin N- terminal ucundaki valin aminoasidine glukoz eklenmesi ile oluşan kararsız bir schiff bazı ( aldimin, pre-HbA1c) olduğu ortaya konmuştur. Meydana gelen bu schiff bazı parçalanabilir veya amadori reaksiyonuna girerek kararlı ketoamin, HbA1c oluşturur ${ }^{6,7}$. HbA1c glukoproteinin \%80'ini oluşturmaktadır ${ }^{8}$. Sağllklı bir şekilde HbA1c nin yorumlanması eritrosit ömrünün normal (120 gün) olmasına bağlıdır. Hemolitik hastalık veya eritrosit ömrünü kısaltan hastalıklar glukohemoglobin düzeyinde önemli ölçüde azalmaya neden olur. Demir eksikliği olan vakalarda yaşlı eritrositlerin yüksek oranda olmasından dolayı HbA1c düzeyi normalden yüksek bulunabilir. Demir eksikliği anemisinde artan oksidatif stres sonucu salınan inflamasyon moleküllerinin hemoglobinin glikasyonunu artırması, DEA'de azalan total hemoglobin konsantrasyonuna bağl1 glikozile hemoglobin oranının göreceli artması, DEA'sinde dolaşımdaki yaşlı eritrositlerin oranının artmasından dolayı HbA1c düzeylerinin yüksek olduğu açıklanmaya çalışılmıştır. ${ }^{9,10}$. Yaşlı eritrositlerdeki HbA1c seviyeleri genç olanlara göre daha yüksektir. Hemolitik anemi ve akut kanamalarda HbA1c düzeyleri normalden daha düşük bulunabilir. Üremik hastalarda da eritrosit yaşam süresi kısaldığından HbA1c normalden daha düşük bulunur. Bununla birlikte kronik hastalık anemisi ve demir eksikliği anemisinde HbA1c düzeyleri yüksek bulunabilir ${ }^{11-13}$. Diyabetes mellitus ve DEA toplumda sık gözlenen iki hastalıktır. DEA'nin DM'lu hastalarda hem tanı kriteri olan, hem de uzun dönem glukoz regulasyonunu gösteren HbA1c'yi etkilediği birçok çalışmada gösterilmiştir. Çalışmamızda diyabetik olmayan premenopozal kadınlarda DEA'nin HbA1c'ye olan etkisinin değerlendirilmesi amaçlanmıştır.

\section{Gereç ve Yöntem}

Çalışmamıza merkezimiz iç hastalıkları polikliniğine başvuran 18-46 yaş arası premenopozal 91 hasta dahil edildi. $\mathrm{Bu}$ bireylerden hemoglobin değeri $12 \mathrm{mg} / \mathrm{dl}$ altında ve DEA olan 45 birey hasta grup, hemoglobin değeri $12 \mathrm{mg} / \mathrm{dl}$ üzerinde olan sağlıklı 46 birey kontrol grubu olarak sınıflandırıldı. Çalışma için merkezimiz Etik Kurulu'ndan 26.10.2016 tarih ve 08 numaralı oturum, 121 sayılı izin alınmış olup hastaların dosya verileri ve laboratuvar tetkikleri ile retrospektif olarak incelendi. Çalışma için dışlama kriterleri; (i) bilinen DM öyküsü, (ii) insülin direnci oluşturan kortikosteroid gibi ilaçların kullanımı, (iii) son 3 ay içinde demir tedavisi kullanımı, (iv) malignite hikayesi, (v) diğer nedenlere bağlı anemi öyküsü bulunması (hemolitik anemi, talasemi v.b.), (vi) yakın zamanda geçirilmiş akut veya kronik enfeksiyon öyküsü, (vii) Cushing sendromu, karaciğer ve böbrek hastalığı, malignite, malnütrisyon ve malabsorpsiyon durumlarının olması, (vii) demir eksikliği anemisi dışında herhangi bir hastalığın bulunması olarak belirlendi. Çalışmamız retrospektif bir çalışma olduğu için veriler incelenirken postmenopozal kadınların çoğunda diyabet, hipertansiyon, böbrek hastalığ 1 , hipo-hipertiroidi gibi ek hastalıkların olduğu gözlendi. Bu nedenle postmenapozal hastalar çalışma dişı tutuldu.

Hemogram verileri ethylenediaminetetraacetic acid (EDTA) içeren tüplere alınanarak Bt pro 2401 cihazı ile bakıldı. Biyokimya parametreleri (AST, ALT, üre, kreatinin) Cobas 6000 C501 (Roche Diagnostics GmbH, Mannheim, Germany) biyokimya analiz cihaz1 ile tayin edildi. Serum Vitamin B12, folik asid, serum demir, serum demir bağlama kapasitesi, ferritin, HbA1c düzeyleri Cobas e 411 (Roche Diagnostics $\mathrm{GmbH}$, Mannheim, Germany) analiz cihazı ile tayin edildi. Transferin Saturasyon İndeksi; serum demiri /TDBK x100 formülüyle hesapland. Vücut Kitle İndeksi (VKI); Quetlet indeksi kullanılarak hastanın kilosunun, boyunun karesine bölünerek (ağırlık/boy² $\mathrm{kg} / \mathrm{m}^{2}$ ) hesapland 1 .

\section{İstatistiksel Analiz}

Çalışmada elde edilen bulgular değerlendirilirken istatiksel analizler için SPSS 24.0 programı kullanılarak yapıldı (SPSS Inc. Chicago, IL). Değişkenlerin normal dağılımı Kolmogorov smirnov, varyans eşitliği ise Levene testi ile test edildi. Verilerin normal dağ1lım göstermesi sebebiyle tüm analizler parametrik testlerle yapıldı. Sürekli değişkenler ortalama $( \pm)$ standart sapma, kategorik değişkenler ise yüzde olarak ifade edildi. Grup ortalamalarının kıyaslanmasında sayısal değişkenler için Independent-Samples T-Test, kategorik değişkenler için ki kare testi kullanıldı. İkili kıyaslamalarda istatististiksel olarak önemli değerlendirilen parametreler multivariate modele dahil edildi.

\section{Bulgular}

Çalışmamıza dahil edilen hastaların yaş ortalaması DEA olan grupta $32 \pm 10$ y1l, kontrol grubunda ise $30 \pm 8$ y1l idi. DEA olan grup ile kontrol grubunun 


\section{Demir Eksikliği Anemisinde HbA1c}

yaşları arasında istatistiksel olarak anlamlı fark saptanmadı $(\mathrm{p}>0.05)$. Gruplar arasinda kilo, boy ve VKI karşılaştırıldığında istatistiksel olarak anlamlı fark saptanmadi. DEA grubu ile kontrol grubu arasında biyokimyasal kan değerleri yönünden yapılan istatistiksel analizde ALT, AST, üre, kreatinin, vitamin B12 ve folik asid düzeyleri arasında anlamlı bir fark saptanmad1.

DEA grubunun hemoglobin düzeyi $10.0 \pm 1.2 \mathrm{gr} / \mathrm{dl}$ iken kontrol grubunun 14.0 \pm 0.9 gr/dl idi. DEA grubunun hematokrit, MCV ve RDW düzeyleri sırasıyla \%32.2 $\pm 3.1,69.9 \pm 5.7 \mathrm{fl}$ ve $\% 18.6 \pm 2.3$ idi. Kontrol grubunun hematokrit, $\mathrm{MCV}$ ve RDW düzeyleri ise sirasiyla $\% 42.4 \pm 2.7,89.1 \pm 4.1$ fl ve $\% 14.8 \pm 1.1$ saptand1. DEA grubunun serum demir düzeyi $25.2 \pm 8.9$ $\mu \mathrm{g} / \mathrm{dl}$ ve kontrol grubunun serum demir düzeyi $106.3 \pm 36.0 \mu \mathrm{g} / \mathrm{dl}$ saptand. DEA grubunun TDBK düzeyi \%447.3 \pm 41.6 iken kontrol grubunun TDBK düzeyi \%359.2 \pm 38.4 idi. Gruplar arasındaki farkın istatistiksel olarak anlamlı olduğu gözlendi (Tablo I).

Tablo I. Grupların Demografik ve Laboratuvar Özellikleri

\begin{tabular}{|l|c|c|c|}
\hline Parametre & $\begin{array}{c}\text { DEA Grubu } \\
\text { (n:45) } \\
\text { ORT } \pm \text { SS }\end{array}$ & $\begin{array}{c}\text { Kontrol Grubu } \\
\text { (n:46) } \\
\text { ORT } \pm S S\end{array}$ & p değeri \\
\hline Yaş (yll) & $32 \pm 10$ & $30 \pm 8$ & 0.643 \\
\hline VKi $\left(\mathrm{kg} / \mathrm{m}^{2}\right)$ & $25.1 \pm 5.2$ & $23.6 \pm 4.6$ & 0.640 \\
\hline $\mathrm{Hg}(\mathrm{gr} / \mathrm{dl})$ & $10.0 \pm 1.2$ & $14.0 \pm 0.9$ & $<0.001$ \\
\hline HCT(\%) & $32.2 \pm 3.1$ & $42.4 \pm 2.7$ & $<0.001$ \\
\hline MCV(fl) & $69.9 \pm 5.7$ & $89.1 \pm 4.1$ & $<0.001$ \\
\hline TDBK & $447.3 \pm 41.6$ & $359.2 \pm 38.4$ & $<0.001$ \\
\hline TSi $(\%)$ & $5.7 \pm 2.1$ & $30.2 \pm 10.7$ & $<0.001$ \\
\hline Ferritin (ng/ml) & $4.0 \pm 2.0$ & $31.3 \pm 15.4$ & $<0.001$ \\
\hline Glukoz(mg/dl) & $94.2 \pm 5.8$ & $91.2 \pm 7.8$ & $\mathbf{0 . 0 3 9}$ \\
\hline HbA1c $(\%)$ & $5.6 \pm 0.2$ & $5.1 \pm 0.2$ & $<0.001$ \\
\hline
\end{tabular}

DEA: Demir eksikliği anemisi, VKİ: Vücut kitle indeksi, Hg: Hemoglobin, HCT: Hematokrit, MCV: Mean Erythrocyte Volume (Ortalama Eritrosit Hacmi), TDBK: Total demir bağlama kapasitesi, TSİ: Transferrin saturasyon indeksi

DEA grubunun serum glukoz düzeyi, kontrol grubunun serum glukoz düzeyinden yüksek saptandı (sıras1yla; $94.2 \pm 5.8 \mathrm{mg} / \mathrm{dl}$ ve $91.2 \pm 7.8 \mathrm{mg} / \mathrm{dl}, \mathrm{p}=0.039$ ). Aradaki fark istatistiksel olarak anlamlı idi (Şekil 1). Benzer şekilde DEA grubunun HbA1c düzeyi, kontrol grubunun HbA1c düzeyinden istatistiksel anlaml yüksek saptandı (sırasıyla; $\% 5.6 \pm 0.2$ ve $\% 5.1 \pm 0.2$, $\mathrm{p}<0.001)$ (Şekil 2).

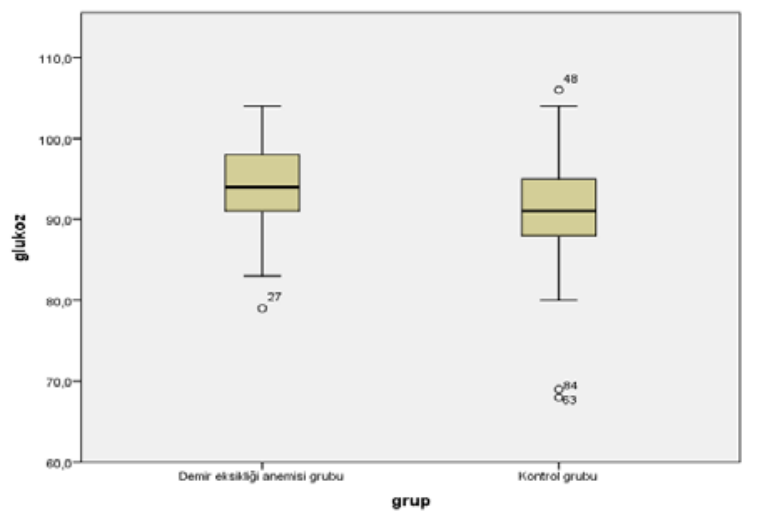

Şekil 1

Grupların Glukoz Düzeyleri

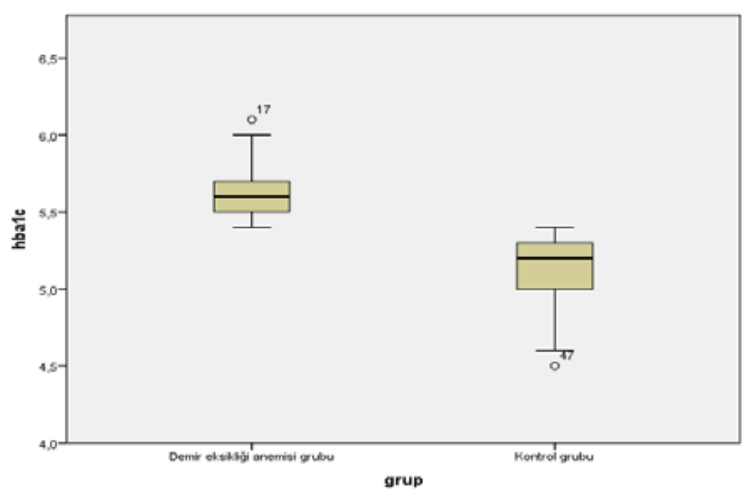

Şekil 2.

Grupların HbAlc Düzeyleri

\section{Tartışma}

Toplam glisemik maruziyet ve uzun dönem komplikasyon riski arasında yüksek ilişki, preanalitik dayanıklılığının daha yüksek oluşu, biyolojik varyasyonunun daha az oluşu, açlık ve eş zamanlı örnek alımı gibi zorunluluklara ihtiyaç duyulmaması, tanı ve tedavi protokollerine ilişkin rehberlerin düzenlenmiş olması ve plazma glukoz düzeylerinde meydana gelen anlık değişimlerinden etkilenmemesi HbA1c için önemli avantajlardır. Bu avantajlar göz önüne alınd1ğında HbA1c ölçümünün, glukoz ölçümüne kıyasla DM tanı ve tedavisinin yönlendirilmesinde giderek daha fazla klinik önem kazandığı söylenebilir. HbA1c için referans aralık (normal değerler) \% 4-6 arasında$\mathrm{dir}^{14}$.

Glukohemoglobin sentezi geri dönüşümsüzdür ve eritrositlerin yaşam süresi ve glukoz konsantrasyonuna bağımlıdır. HbA1c'nin yorumlanması eritrosit ömrünün normal olmasına bağlıdır. Eritrosit ömrünü kısaltan hastalıklar glukohemoglobin düzeyinde önemli ölçüde azalmaya neden olur ${ }^{15}$. Yapılan çalışmalarda genç eritrositlerin olgun eritrositlerden daha düşük düzeyde glikozillenmiş hemoglobin içerdikleri gösterildiğinden, HbA1c'in ortalama eritrosit yaşı ile 
ilişkili bir parametre olduğu bilinmektedir ${ }^{16}$. Hemolitik anemi gibi hastalıklarda ve akut kanamalarda HbA1c düzeyi normalden düşük bulunabilir. Normoglisemik kişilerde eritrosit yaşam süresinin tahmininde de HbA1c seviyelerinin kullanılabileceği bilinmekte$\operatorname{dir}^{17,18}$. Bunun nedeni dolaşımdaki genç eritrositlerin oranının yüksek olmasıdır. DEA'nde HbA1c oranı yüksek bulunmuştur. Bunun muhtemel nedeni olarak da dolaşımdaki yaşlı eritrositlerin oranının artması gösterilmiştir ${ }^{19,20}$. Bununla birlikte hematokrit düzeyindeki değişiklikler plazma hacmindeki olası değişimlere neden olarak hemokonsantrasyona yol açmakta ve HbA1c'yi etkileyebilmektedir ${ }^{21}$.

Sucu ve ark.larının yapmış olduğu bir çalışmada nondiyabetik 222 DEA olan hasta, aynı özelliklerdeki DEA olmayan 476 birey ile karşılaştırılmış ve DEA olan bireylerin ortalama HbA1c düzeylerinin anlaml yüksek olduğu saptanmıștır ${ }^{22}$. Hansen ve ark.larının yapmış olduğu bir çalışmada ise DEA olan 10 hastada, 10 sağlıklı kontrol grubundan farksız buldukları HbA1c konsantrasyonunun, DEA olan gruba verilen demir tedavisi sonrasında anlamlı olarak düştüğü gözlenmiştir. $\mathrm{Bu}$ durumun nedeninin demir eksikliği anemisinde hemolitik komponentin çok az olması ve demir replasmanı sonrası artan yeni ve immatur eritrositlerin HbA1c konsantrasyonunu azaltması olduğunu öne sürerek glukozile hemoglobinin özellikle immatür eritrosit yapımının arttığı eritrosit populasyon değişikliklerinin duyarlı bir göstergesi olduğunu ifade etmişlerdir ${ }^{23}$.

Alıcı ve ark.larının yapmış olduğu bir çalışmada demir eksikliği anemisinde HbA1c ve fruktozamin değerleri arasındaki ilişkiyi değerlendirilmiştir. Bu çalışmada; diyabeti olmayan DEA grubunda demir tedavisi öncesi HbA1c düzeyi \%5.74 \pm 0.66 iken, tedaviden 6 hafta sonra HbA1c düzeyi \%5.23 \pm 0.40 saptanmıştır. Fark istatistiksel olarak anlamlıdır ${ }^{24}$. Erkan ve ark.larının yapmış olduğu bir çalışmada, DEA olan grupta demir tedavisinden önce ve sonra ortalama HbA1c düzeyleri sirasiyla $\% 7.4 \pm 0.8$ ve $\% 6.2 \pm 0.6$ olup istatistiksel anlamlı fark gözlenmiştir. Aynı çalışmada nondiyabetik hastalarda DEA olan gruptaki ortalama açlık kan şekerleri demir tedavisinden önce ve sonra 91.4 \pm 9.8 $\mathrm{mg} / \mathrm{dL}$ ve $92.1 \pm 9.4 \mathrm{mg} / \mathrm{dL}$ olup istatistiksel anlamlı fark saptanmamıştır ${ }^{25}$. Bir başka çalışmada DEA olan 50 hasta ile herhangi bir hastalığı olmayan 50 sağlıklı bireyin HbA1c düzeyleri ölçülmüş ve DEA grubunda HbA1c anlamlı yüksek bulunmuştur ${ }^{26}$.

Kim ve ark.ları diyabetik olup olmadığı bilinmeyen 6666 kadın ve 3869 erkeği kapsayan araştırmalarında, kadınlarda demir eksikliğinin glukoz düzeylerinden bağımsız olarak, \%5.5- \%6.5 arasında olan HbA1c düzeylerinde hafifçe ve yukarı doğru bir kaymaya yol açtığını göstermişlerdir ${ }^{27}$. Bir başka çalışmada da DEA olan hastalara verilen oral demir tedavisinden sonra HbA1c ortalama seviyelerinin \%6.15 0.6 'den $\% 5.25 \pm 0.25$ seviyesine gerilediği gösterilmiş- tir. $\mathrm{Bu}$ araştırmalarda $\mathrm{HbA} 1 \mathrm{c}$ artışına neden olarak, kan glukozunun sabit olduğu ancak hemoglobin konsantrasyonunun düştüğü DEA nde total hemoglobinin glukolize fraksiyonunda göreceli bir artış olduğu öne sürülmüştür ${ }^{28}$.

Literatürdeki bu çalışmaların aksine Van Heyningen ve ark.larının yapmış olduğu bir çalışmada diyabet olmayan hastalarda DEA olan grupta demir tedavisi öncesi ve sonrasinda HbA1c seviyesinde herhangi bir değişiklik saptanmamıştır ${ }^{29}$. Sinha ve ark.larının yaptıkları bir çalışmada ise diğer tüm araştırmacıların aksine, DEA olan 55 hastanın $\mathrm{HbA1c}$ düzeylerini (\%4.6) kontrol grubununkinden (\%5.5) anlamlı düşük bulduklarını ve DEA olan hastaların 2 aylık demir tedavisi sonrası HbA1c düzeylerinde yükselme saptadıklarını rapor etmişlerdir. $\mathrm{Bu}$ sonuca neden olan durumların da beslenme faktörleri ya da bilinmeyen bir başka faktör olabileceğini öne sürmüşlerdir ${ }^{30}$. Başka bir çalışmada hemoglobin ile HbAlc arasında istatistiksel anlamlı pozitif korelasyon bildirmiştir. Hemoglobin $10 \mathrm{~g} / \mathrm{dl}$ 'nin altında HbA1c \%5.28, Hemoglobin $17 \mathrm{~g} / \mathrm{dl}$ 'nin üzerinde HbA1c \%5.72 saptanmış$\mathrm{t}^{31}$.

Brooks ve ark.larının yaptıkları bir çalışmada, demir eksikliği hemoglobin molekülünün dörtlü şeklini değiştirebilir ve bundan dolayı beta globulin daha kolay glukolize olabilir fikrini öne sürmüşlerdir ${ }^{32}$. HbA1c ölçümü açısından farklı yöntemlerin farklı sonuçlar doğurabileceği birçok çalışmada öne sürülmüştür. Öte yandan Rai ve arkadaşları HbA1c ölçümü için farklı yöntemleri karşılaştırdığı araştırmasında, kalorimetrik metod, iyon değişim kromotografisi ve affinite kromatografisi arasında fark olmadığını tespit etmişlerdir ${ }^{33}$.

Diyabetik olsun ya da olmasın erişkinlerde DEA'nin değişik yöntemlerle ölçülmüş HbA1c düzeylerine olan etkisini inceleyen çalışmaların sonuçlarının çok çelişkili olduğu görülmektedir. Yapılan araştırmalarda DEA'nin HbA1c düzeylerine etkisi tam olarak aydınlatılamamıştır. Kore'de yapılan bir çalışmada erişkin popülasyonda DEA varlığı ile HbA1c seviyeleri arasında birliktelik incelenmiş; DEA varlığında HbA1c seviyelerinin açlık plazma glukozu seviyesinden bağımsız olarak hafifçe yüksek olduğu saptanmıştır. DEA varlığında HbA1c seviyelerindeki değişimi diyabetik olmayan veya prediyabetik olan grupta saptamışlar ancak AKŞ seviyesi $\geq 126 \mathrm{mg} / \mathrm{dl}$ olan diyabetik grupta bu değişimi gözlemlememişler. Ayrıca DEA varlığ $1 \mathrm{HbA1c}$ seviyesinin \% 6,5'dan küçük olan grubu daha ağırlıklı etkilerken HbA1c \% 6,5'dan yüksek olan grubu etkilemediğini saptamışlar. $\mathrm{Bu}$ durumu DEA'nin HbA1c'ye etkisinde bir çok faktör rol oynadığından dolayı olduğunu vurgulamışlar, bu çalışmalar diyabet olmayan popülasyonlarda yapılmış olması sebebiyle DEA'nin varlığının HbAlc seviyelerini, ADA'nın diagnostik cutoff değeri olan $<6,5 \%$ 'a karşı $\geq 6,5 \%$ değerlerinde etkileyip etkilemediği değerlendirilememiştir. Ancak, yüksek populasyonlu bu çalış- 


\section{Demir Eksikliği Anemisinde HbA1c}

mada tedavi almayan diyabetlilerde DEA'nin varlığ nın normoglisemik ve prediabetik gruplarda $\mathrm{HbAlc}$ seviyesini yukarı çektiğini gözlemlemişler. DEA'nin, HbAlc değeri $\geq 6,5 \%$ olan veya $A K S ̧$ değeri $\geq 126$ $\mathrm{mg} / \mathrm{dl}$ olan grubu etkilemediğini saptamışlardır ${ }^{34}$. 1999-2006 NHANES verilerine dayanarak yapılan bir çalışmada diyabet olmayan kadınların HbAlc seviyelerinin demir eksikliği olması durumunda $<5,5 \%$ değerinden $\geq 5,5 \%$ değerine kaydığı gösterilmiştir ${ }^{27}$.

DEA olan hastaların HbA1c seviyelerinin neden yükseldiği hala tam olarak açıklanamamıştır. Muhtemel nedenler arasında Hb'nin kuarterner yapısındaki değişimler ve $\beta$ globin zincirindeki glikasyonun DEA hastalarında kolaylaşmış olması ihtimali üzerinde durulmaktadır ${ }^{35}$. El-Agouza ve arkadaşlarının çalışmasinda $\mathrm{Hb}$ konsantrasyonundaki azalma belli bir kan glukozu seviyesinde glikasyonu kolaylaştırmakta ve bu yüzden $\mathrm{HbA1c}$, total HbA oranı içinde ölçülmektedir şeklinde bir öneri gelmiştir ${ }^{36}$. DEA hastalarındaki eritrositlerin uzamış yaşam süresi de HbA1c seviyesinin yüksek çıkmasında etkilidir ${ }^{37}$. Bazı çalışmalar ise DEA olduğu durumlarda normal hatta kısalmış eritrosit yaşam döngüsü olduğunu da bildirmişlerdir. $\mathrm{Bu}$ fenomenin mekanizmasını açıklamak için ileri çalışmalara ihtiyaç duyulmaktadır ${ }^{38-40}$. Yapılan araştırmalarda DEA'sinin HbA1c düzeylerine etkisi tam olarak aydınlatılmamıştır. Demir eksikliği anemisinde artan oksidatif stres sonucu salınan inflamasyon moleküllerinin hemoglobinin glikasyonunu artırmas1, DEA'de azalan total hemoglobin konsantrasyonuna bağl1 glikozile hemoglobin oranının göreceli artması, DEA'sinde dolaşımdaki yaşlı eritrositlerin oranının artmasından dolayı $\mathrm{HbA1c}$ düzeylerinin yüksek olduğu açıklanmaya çalışılmıştır.

Çalıșmamızda DEA olan grubun HbA1c düzeyi, kontrol grubunun $\mathrm{HbA} 1 \mathrm{c}$ düzeyinden yüksek saptanmıştır

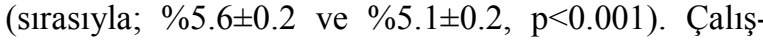
mamızda da, yapılan birçok çalışmada olduğu gibi, HbA1c düzeyi DEA olan grupta istatiksel olarak anlamlı yüksek saptanmıştır. Ancak çalışmamızın kesitsel küçük bir grup olması, retrospektif olması ve bundan dolayı demir eksikliği olan grubun tedavi sonrası HbA1c düzeyine bakılamamış olması çalışmamızın kısıtlayıcı yönleridir. DEA'nin HbA1c düzeyleri üzerine etkisini değerlendirmeye yönelik, diyabetik olan ve olmayan kişilerde daha geniş ölçekli çalışmalara ihtiyaç vardır. Bununla birlikte diabetes mellitusun tanı ve izleminde $\mathrm{HbAlc}$ düzeyleri yorumlanırken DEA ve diğer olası hata kaynakları konusuna dikkat edilmesi gerektiği kanaatine varılmıştır. DEA'nin etkin tedavisinin aneminin olumsuz etkilerini ve HbA1c'nin yorumlanmasında oluşacak hataları ortadan kaldıracağı düşünülmektedir.

\section{Kaynaklar}

1. Ünal S, Yetgin S. Demir eksikliği anemisi. Sosyal pediatri. Katk1 dergisi 2003;(3): 327-345.

2. Acharya J, Punchard NA, Taylor JA, Thompson PR, Pearson TC. Red cell lipid peroxidation and antioxidant enzymes in iron deficiency. Eur J Haematol 1991;47: 287-91.

3. Neyzi O, Ertuğrul T. Pediatri. Cilt 1.2.B. İzmir: Nobel Tip Kitapevleri; 1993. s.373.

4. Ali R. Demir eksikliği anemisi. In Dolar E. İç hastalıkları. 1.B. İstanbul; Nobel Tip Kitapevleri: 2005.s.553- 57.

5. American Diabetes Association. Standards of medical care in diabetes-- 2010. Diabetes Care. 2010 Jan;33 Suppl 1: S11-61.

6. Harris RA, Crabb D. W. Metabolic Interrelationships. In Devlin TM. Textbook of Biochemistry with Clinical Correlations, New York: Wiley-Liss, 2002: 862-902.

7. Calbreath DF. Carbohyrate biochemistry. In: Calbreath DF, edition. Clinical Chemistry A Fundamental Text book. Philadelphia: WB Saunders, 271-2, 1992.

8. Sacks DB, Path FR. Carbohydrates. In Carl A. Burtis, Edward R. Ashwood, David E. Bruns. Tietz Textbook of Clinical Chemistry and Molecular Diagnostics, Philadelphia: Elsevier Saunders, 2006: 837-902.

9. Başkal N. Diabetes Mellitusun Sınıflandırılması. İçinde; Koloğlu. Endokrinoloji Temel ve Klinik; Prof Dr. Gürbüz Erdoğan (Editör), MN Medikal and Nobel. Ankara. 2005: 342-348.

10. American Diabetes Association. Report of The Expert Comittee on The Diagnosis Classification of DM. Diabetes Care, 2000;23(Supl): 4-9.

11. Jovanovic L, Peterson CM. The clinical utility of glycosylated hemoglobin. Am J Med. 1981 Feb;70(2): 331-8.

12. Gram-Hansen P, Mourits-Andersen HT, Eriksen JE, Olesen LL. [Glycosylated hemoglobin (HbA1c) and acute hemolytic anemia]. Ugeskr Laeger. 1990 Feb 12;152 (7): 477-9.

13. Jiao Y, Okumiya T, Saibara T, Park K, Sasaki M. Abnormally decreased HbA1c can be assessed with erythrocyte creatine in patients with a shortened erythrocyte age. Diabetes Care. 1998 Oct;21(10): 1732-5

14. Genc S, Omer B, Aycan-Ustyol E, Ince N, Bal F, Gurdol F. Evaluation of turbidimetric inhibition immunoassay (TINIA) and HPLC methods for glycated haemoglobin determination. J Clin Lab Anal. 2012 Nov;26(6): 481-5. doi: 10.1002/jcla.21550.

15. Dinçol G, Pekçelen Y, Atamer T. Klinik Hematoloji. Nobel Tıp Kitapevi İstanbul 2003.

16. Alıcı S, Dülger HH. Hemoglobinlerin nonenzimatik glikozilasyonu. Van Tip Dergisi.2001;8(3): 105-110.

17. Sluiter WJ, van Essen LH, Reitsma WD, Doorenbos H. Glycosylated haemoglobin and iron deficiency. Lancet 1980;6;2: 531-2.

18. Mitchell TR, Anderson D, Shepperd J. Iron deficiency, haemochromatosis, and glycosylated haemoglobin. Lancet 1980; 4;2: 747.

19. Tietz textbook of clinical chemistry. Carl A.Burtis, Ph.D.Edward .Ashwood,M.d.Third EDİtion.2003.790-796.

20. Harrison's principles of internal medicine. Braunwald,Faunci, Kasper, Hause R, Longo, Jarneson, 2019-2025,15th edition.

21. Glycosylatedhemoglobin.https://ahdc.vet.cornell.edu/clinpath/modules/chem/glycos.h tm Roerdinkholder-Stoelwinder

22. Sucu V, Yıldırmak S, Durmuşcan M, Yetiškinlerde Demir eksikliği Anemisi ve Hemoglobin A1c Düzeyleri Arasındaki İlişki Türk Klinik Biyokimya Derg 2015;13(1): 7-14. 


\section{E. Atalay, ark.}

23. Gram-Hansen P, Eriksen J, Mouritis-Andersen T, Olesen L. Glycosylated haemoglobin Deficiency (HbA1c) in iron- and vitamin B12. Intern Med 1990;227: 133-36.

24. Alıcı S, Vural H, Ecirli Ş. Demir Eksikliği Anemisinde HbA1c ve Fruktozamin Değerleri.http://www.ichastaliklaridergisi.org/ managete/fu_folder/1997-06/html/1997-4-6-371-375.html Erişim Tarihi:20.06.2013.

25. Erkan C, Mustafa O, Aysen T. Effect of iron deficiency anemia on the levels of Hemoglobin A1c in nondiabetic patients. Acta Haematol 2004;112: 126-8.

26. Shanthi B, Revathy C, Manjula Devi AJ, Subhashree. Effect of iron deficiency on glycation of haemoglobin in nondiabetics. J Clin Diagn Res 2013;7: 15-7.

27. Kim C, Bullard KM, Herman WH, Beekles GL. Association Between Iron Deficiency and HbA1c Levels Among Adults Without Diabetes İn the National Health and Nutrition Examination Survey, 1999-2006 Diabetes Carel 2010;33: 780-5.

28. El-Agouza I, Abu Shahla A, Sirdah M. The effect of iron deficiency anaemia on the levels of haemoglobin subtypes: possible consequences for clinical diagnosis. Clin Lab Haem 2002;24: 285-9.

29. Van Heyningen C, Dalton RG. Glycosylated hemoglobin in iron deficiency anemia. Lancet 1985;1: 874.

30. Sinha N, Mishra TK, Singh T and Gupta N. Effect of Iron Deficiency Anemia on Hemoglobin A1c Levels. Ann Lab Med 2012;32: 17-22.

31. Ford ES, Cowie CC, Li C, Handelsman Y, Bloomgarden ZT Iron-deficiency anemia, non-iron-deciency anemia and HbA1c among adults in the US. J Diabetes 2011;3(1): 67-73.
32. Brooks AP, Metcalfe J, Day JL, Edwards MS. Iron deficiency and glycosylated haemoglobin A1. Lancet 1980 Jul 19;2(8186): 141.

33. Rai KB, Pattabiraman TN: Glycosylated haemoglobin in irondeficiency anaemia. Indian J Med 1986; 83:234-6. 37. Madhikarmi NL, Murty KR. Antioxidant enzymes and oxidative stres in the erythrocytes of iron deficiency anemic patients supplemented with vitamins. Iran Biomed J 2014;18: 82-7.

34. Jae W. Hong, Cheol R. Ku, Jung H. Noh. ; Association Between the Presence of Iron Deficiency Anemia and Hemoglobin A1c in Korean Adults (Medicine 94(20):e825)

35. Christy AL, Manjrekar PA, Babu RP, Hegde A, Rukmini MS. Influence of Iron Deficiency Anemia on Hemoglobin A1C Levels in Diabetic Individuals with Controlled Plasma Glucose Levels. Iran Biomed J 2014;18: 88-93.

36. El-Agouza, I., A. Abu Shahla, and M. Sirdah. "The effect of iron deficiency anaemia on the levels of haemoglobin subtypes: possible consequences for clinical diagnosis." Clinical \& laboratory haematology 24.5 (2002): 285-289.

37. Gallagher EJ, Le Roith D, Bloomgarden Z. Review of hemoglobin $\mathrm{A}(1 \mathrm{c})$ in the management of diabetes. J Diabetes. 2009;1:9-17.

38. Verloop MC, van der W, Heier AJ. Radioactive iron studies in patients with iron deficiency anemia with concurrent abnormal hemolysis. Blood. 1960;15:791-806

39. Rasch CA, Cotton EK, Griggs RC, et al. Shortened survival of autotransfused 51Cr-labeled erythrocytes in infants with severe irondeficiency anemia. Semin Hematol. 1976;13:181-186.

40. Temperley IJ, Sharp AA. The life span of erythrocytes in irondeficiency anaemia. J Clin Pathol. 1962;15:346-349. 